\title{
MERANCANG SISTEM INFORMASI PEMBAYARAN UANG SEKOLAH PADA SUNBRIGHT INTERNATIONAL PRESCHOOL
}

\author{
Sugesti ${ }^{1}$ \\ Gunawan Putrodjojo $^{2}$ \\ Fergie Florencia Tandella ${ }^{3}$ \\ Dosen Tetap STMIK Dharma Putra, Tangerang ${ }^{1}$, Dosen Tetap/DTYM STMIK Raharja, Tangerang ${ }^{2}$, \\ Alumni STMIK Dharma Putra, Tangerang ${ }^{3}$ \\ Jl. Otto Iskandaradinata (Otista) No. 80, Tangerang ${ }^{1}$, Jl. Jendral Sudirman No. 40, Modernland, Tangerang ${ }^{2}$, \\ $\mathrm{Jl}$. Otto Iskandaradinata (Otista) No. 80, Tangerang3 \\ E-mail : gesti74@gmail.com ${ }^{1)}$,gunawan.putrodjojo@ raharja.info ${ }^{2}$, fergie.floren@yahoo.com ${ }^{3)}$
}

\begin{abstract}
ABSTRAK
Sunbright International Preschool (SIP) memiliki tujuan di bidang sosial, keagamaan dan kemanusiaan. Oleh karena itu dalam anggaran dasarnya SIP akan bergerak di beragam kegiatan lintas sektoral seperti Sekolah, Riset ilmiah, studi banding, mengunjungi sarana ibadah, dan lain sebagainya. Untuk mendukung sistem pendidikan yang bermutu perlu adanya suatu sistem yang bisa membantu kinerja petugas tata usaha. Dalam kegiatan transaksi pembayaran uang sekolah, tentu adanya sebuah sistem yang diberlakukan demi kelancaran transaksi tersebut. Untuk memudahkan dalam hal proses pengolahan data transaksi yang terjadi sampai pada pembuatan laporan, sangat dibutuhkan suatu Sistem Informasi pembayaran uang Sekolah. Karena Sistem Informasi Administrasi merupakan langkah awal untuk dapat terlaksananya suatu kegiatan. Pembayaran uang Sekolah yang selama ini digunakan masih sangat sederhama (semi komputerisasi) yang hanya menggunakan Microsoft excel, maka sering terjadi kesalahan pada saat pencatatan data dan laporan yang dihasilkan datanya belum tentu akurat. Berdasarkan permasalahan di atas maka dibutuhkan suatu sistem yang dapat mengurangi terjadinya kesalahan pada saat input data dan dapat menghasilkan laporan yang datanya akurat dan sistem yang dapat mempunyai penyimpanan agar data yang ada tidak hilang. Sehingga proses pembayaran uang Sekolah dapat berjalan dengan efektif dan efisien. Metode perancangan system yang digunakan adalah SDLC (System Development Life Cycle) yang meliputi Perencanaan, Analisis, Desain, Testing dan Implementasi. Sistem yang dibuat memiliki kemampuan mulai menginpt data uang sekolah, melakukan koreksi/edit, membuat jurnal, dan mencetak laporan baik harian, mingguan, bulanan, maupun tahunan. Sistem juga sudah dilengkapi security baik menggunakan user login pada masing-masing level maupun security bentuk lainnya.
\end{abstract}

Kata Kunci: Pembayaran uang sekolah, Sistem Informasi, dan Pengolahan data.

\section{PENDAHULUAN}

Ilmu pengetahuan dan teknologi informasi saat ini sudah berkembang sangat pesat, sehingga peranan komputer sangat membantu untuk menyelesaikan pekerjaan dalam berbagai bidang pekerjaan dan pendidikan karena dengan penggunaan komputer dapat menghemat waktu, biaya sehingga bisa memberikan hasil yang memuaskan.

Pendidikan adalah salah satu penentu masa depan. Pendidikan dapat diraih baik melalui pendidikan formal maupun non formal. Pendidikan formal dapat diwujudkan melalui bangku sekolah baik sekolah milik pemerintah maupun sekolah milik swasta. Untuk menunjang proses belajar mengajar di sekolah, tentu adanya sebuah kewajiban yang dibebankan kepada para siswa yaitu biaya administrasi yang harus dibayar.

Dalam kegiatan transaksi pembayaran uang sekolah, tentu adanya sebuah sistem yang diberlakukan demi kelancaran transaksi tersebut. Sistem tersebut mencakup prosedur yang digunakan dalam pembayaran uang 
sekolah, bagaimana dalam hal pencatatan transaksi yang terjadi. Untuk memudahkan proses pengolahan data transaksi yang terjadi sampai kepada pembuatan laporan, sangat dibutuhkan sebuah sistem informasi pembayaran uang sekolah. Karena sistem informasi administrasi merupakan langkah awal untuk dapat terlaksananya suatu kegiatan. Sistem pembayaran uang sekolah pada SIP yang berjalan saat ini masih semikomputerisasi sehingga memperlambat kinerja dari bagian tata usaha.

\section{PERMASALAHAN}

Permasalahan yang ada setelah dilakukan suatu pengamatan adalah :

1. Sistem pembayaran uang sekolah yang berjalan saat ini belum efektif dan efisien karena masih dijalankan secara manual.

2. Bukti pembayaran hanya menggunakan kartu bayaran yang diberikan paraf dan stempel.

3. Pembuatan laporan uang sekolah yang berjalan saat ini memakan waktu yang lama dan data yang dihasilkan belum tentu akurat, hal ini disebabkan karena masih sering terjadinya kesalahan pada proses pencataan data.

\section{PEMECAHAN MASALAH}

Untuk memecahkan permasalahn di atas perlu kiranya dirancang suatu solusi bagi masing-masing permasalahn yang ada sebagai berikut:

1. Dibuat pembayaraan Uang Sekolah dengan Sistem.Informasi yang akurat mulai dari input data sampai dengan pelaporannya.

2. Setelah menerima Uang bayaran sekolah, sebaiknya langsung dicetak sebagai bukti bayar yang sah. Pada hasil cetakan (print out) perlu diubuhi tanda tangan dan cap sebagau bukti pengesahan. Hal ini sangat perlu dilakukan mengingat segala sesuatu harus memiliki sistem verifikasi yang akurat.

3. Penerimaan pembayaran uang sekolah langsung diinput pada Aplikasi Sistem Informasi saat penerimaan uang bayaran dari siswa sehingga data dapat disimpan secara akurat. Bila data yang tersimpan adalah data yang akurat maka pada pencetakan laporan pun akan menghasilkan output yang akurat.

\section{TUJUAN}

Dari permasalahan yang telah disampaikan, artikel pada makalah ini bertujuan:

Tujuan Operasional

1. Mengetahui sejauh mana sistem yamg berlangsung pada SIP .

2.Mengetahui lebih lanjut serta menganalisis permasalahan yang ada dalam proses Pembayaran Uang Sekolah pada SIP baik dari awal proses sampai dengan pelaporan yang dilakukan.

Tujuan Fungsional

1.Untuk mengetahui kemampuan penggunaan sistem komputer di SIP dalam pengolahan pembayaran Uang Sekolah.

2.Memberikan usulan sistem yang dapat mengatasi masalah-masalah yang ada baik dari sistem yang sedang berjalan sekarang maupun permasalhan yang mungkin akan muncul saat mendatang.

\section{PEMBAHASAN}

\section{Deskripsi Umum SIP}

SIP merupakan lembaga pendidikan yang berdiri pada tahun 2013, yang berfungsi sebagai unit pelaksana pendidikan jalur sekolah, secara garis besar memiliki tanggung jawab yaitu pelaksana pendidikan selama jangka waktu tertentu sesuai jenis dan sifat sekolah tersebut, melaksanakan pendidikan dan pengajaran 
sesuai dengan kewajiban yang berlaku, melaksanakan bimbingan dan penyuluhan bagi siswa di sekolah, melaksanakan urusan Tata Usaha (TU), membina kerjasama dengan orang tua siswa, masyarakat dan instansi terkait melaksanakan Program Dinas Pendidikan Kabupaten Tangerang, bertanggung jawab kepada Bupati melalui Kepala Dinas Pendidikan Kabupaten Tangerang.

SIP memiliki tujuan di bidang Sosial, Keagamaan dan Kemanusiaan. Oleh karena itu dalam Anggaran Dasarnya SIP akan bergerak di beragam kegiatan lintas sektoral seperti sekolah, riset ilmiah, studi banding, mengunjungi sarana ibadah, dan lain sebagainya.

\section{Uraian Prosedur}

1. Prosedur dalam pembayaran Uang Sekolah adalah sebagai berikut:

a. Siswa datang dengan membawa kartu iuran siswa yang diberikan kepada bendahara untuk membayar biaya Uang sekolah.

b.Bendahara mencatat setiap pembayaran ke buku penerimaan administrasi . Dan menstempel kartu iuran siswa.

2. Prosedur dalam pencatatan transaksi untuk pembuatan laporan

a. Penerima iuran akan merekapitulasi transaksi penerimaan pembayaran Uang Sekolah ke daftar iuran.

b.Penerima iuran akan melaporkan jumlah penerimaan dan pengeluaran kepada kepala sekolah dalam bentuk laporan.

\section{Analisis Proses yang Berjalan Use Case Diagram}

Setelah skenario mengenai sistem pembayaran Uang Sekolah yang berjalan saat ini selesai didefinisikan, maka skenario tersebut akan digambarkan ke dalam bentuk diagram agar dapat mudah dibaca. Dari definisi skenario di atas dapat digambarkan dalam use case diagram mengenai kebiasaan yang terjadi dalam sistem pembayaran Uang Sekolah yang berjalan saat ini. Use case diagram akan menggambarkan hubungan use case dengan actor. Use case diagram dilihat pada gambar di bawah ini :

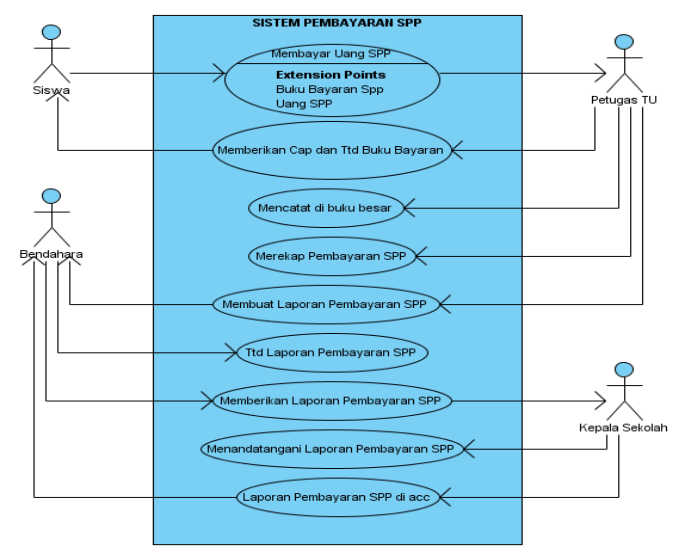

Gambar 1. Use Case Diagram Pembayaran

Berdasarkan gambar 1. Use Case Diagaram yang berjalan di atas terdapat:

a. 1 (satu) sistem yang mencakup seluruh kegiatan pembayaran Uang Sekolah pada SIP.

b. 4 (empat) actor yang melakukan kegiatan, yaitu Siswa, Petugas TU, Bendahara dan Kepala Sekolah.

c. Ada 8 (delapan) use case yang biasa dilakukan oleh actor-actor tersebut diantaranya: memberikan cap dan ttd buku pembayaran, membuat di buku besar, merekap pembayaran Uang Sekolah, membuat laporan pembayaran Uang Sekolah, ttd laporan pembayaran Uang Sekolah, memberikan laporan pembayaran Uang Sekolah, menandatangani laporan pembayaran Uang Sekolah, laporan pembayaran Uang Sekolah di acc.

d. 1 (satu) Extend yaitu membayar uang Uang Sekolah (membawa uang Bayaran dan membawa buku bayaran).

\section{Activity Diagram}

Activity diagram memodelkan alur kerja sebuah proses dan urutan aktivitas pada suatu proses. Diagram ini sangat mirip dengan flowchart karena kita dapat memodelkan prosedur logika. Perbedaan utamanya adalah flowchart digunakan 
untuk menggambarkan alur kerja dari sebuah sistem, sedangkan activity diagram dibuat untuk menggambarkan aktivitas dari actor. Berdasarkan use case diagram di atas dapat kita gambarkan activity diagram dari aktivitas para actor yang ada pada sistem pembayaran administrasi pada SIP.

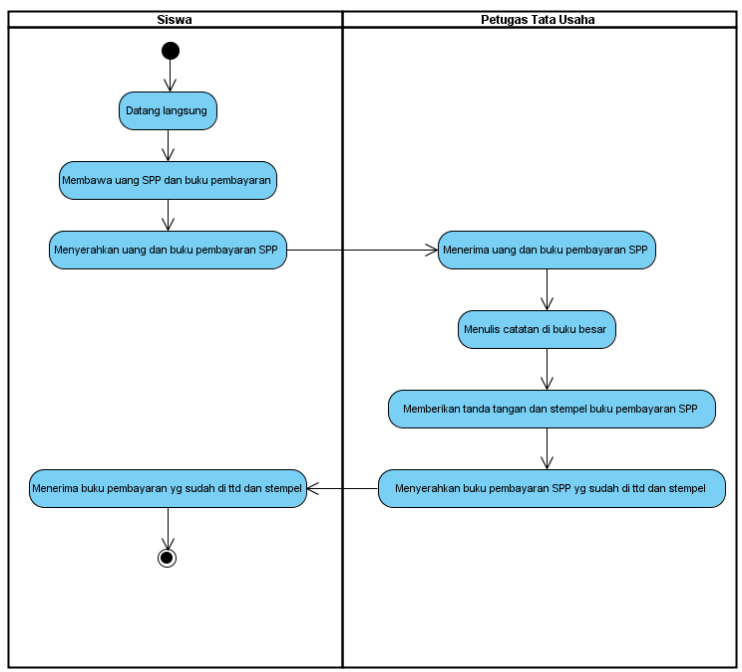

Gambar 2. Activity Diagram Pembayaran Uang Sekolah

Berdasarkan gambar 2. Activity Diagram yang berjalan terdapat :

a. 1 (satu) intial node, objek yang diawali.

b. Ada 8 (tujuan) Activity dari sistem dari sistem yang mencerminkan eksekusi dari suatu aksi diantaranya : Datang langsung, membawa uang Uang Sekolah dan buku pembayaran, menyerahkan uang dan buku pembayaran, menerima uang dan buku pembayaran Uang Sekolah, menulis catatan di buku besar, memberikan ttd dan stempel buku pembayaran Uang Sekolah, menyerahkan buku pembayaran Uang Sekolah yg sudah di acc dan menerima buku pembayaran yg sudah di ttd dan stempel.

c. 1 (satu) final node, objek yang diakhiri.

d. 1 (satu) vertical swimelane yaitu Siswa dan petugas Tata Usaha.

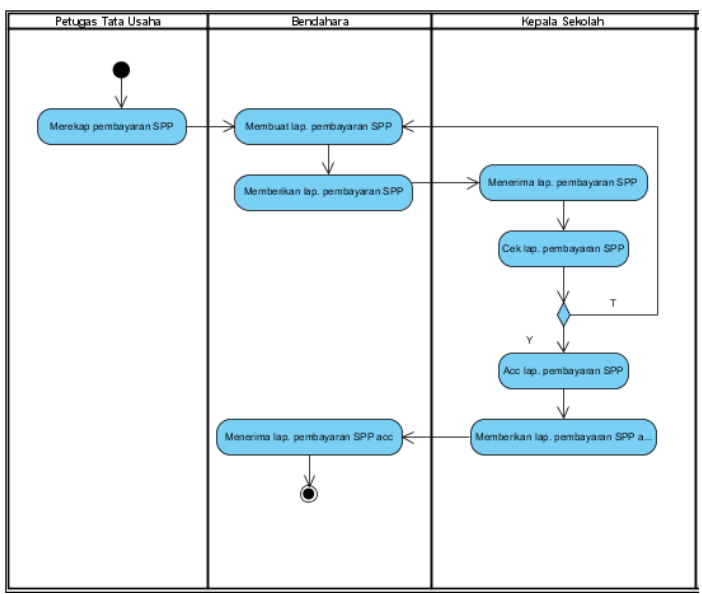

Gambar 3. Activity Diagram Laporan Pembayaran Uang Sekolah

Berdasarkan gambar 3. Activity Diagram yang berjalan terdapat :

a. 1 (satu) intial node, objek yang diawali.

b. Ada 8 activity dari sistem yang mencerminkan eksekusi dari suatu aksi diantaranya : Merekap pembayaran Uang Sekolah, Membuat lap. pembayaran Uang Sekolah, Memberikan lap. pembayaran Uang Sekolah, Menerima lap. pembayaran Uang Sekolah, Cek lap. pembayaran Uang Sekolah, Acc lap. pembayaran Uang Sekolah, Memberikan lap. pembayaran Uang Sekolah acc dan Menerima lap. pembayaran Uang Sekolah acc.

c. 1 (satu) final node, objek yang diakhiri.

b. 1 (satu) vertical swimelane yaitu petugas Tata Usaha, Bendahara dan Kepala Sekolah.

c. d.1 (satu) decision node untuk pemilihan kondisi

\section{Usulan Prosedur}

Dalam menganalisis usulan prosedur yang baru, pada penelitian ini digunakan program Visual Paradigm for UML 6.4. Profesional Edition untuk menggambarkan Use Case Diagram, Class Diagram, Sequence Diagram, Activity Diagram dan Statechart Diagram.

Diagram Rancangan Sistem 


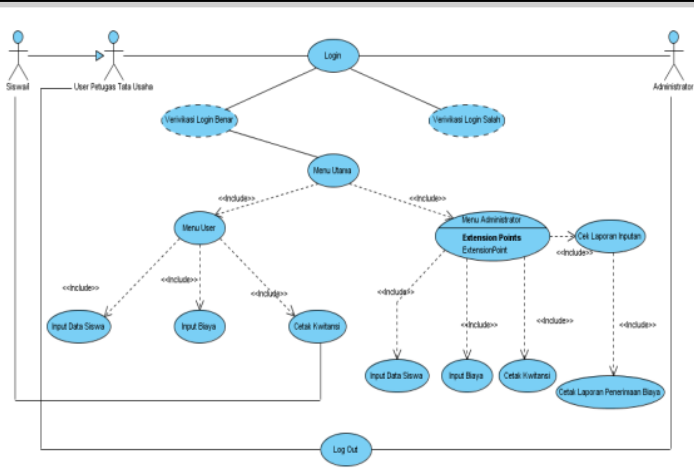

Gambar 4. Use Case Diagram Sistem admin Pembayaraan Uang Sekolah

Berdasarkan gambar 4. Use Case Diagram yang diusulkan, dimulai dari Siswa/i yang membayarkan uang sekolah kepada bagian TU yang diterima oleh admin TU (user) dan menginput pada program yang sudah disediakan lalu admin tata usaha mencetak kwitansi untuk diberikan pada Siswa/i sebagai bukti pembayaran, Fungsi administrator ialah, orang yang bertanggung jawab mengontrol program serta ia juga dapat mencetak laporan penerimaan pembayaraan uang sekolah.

\section{Activity Diagram Admin}

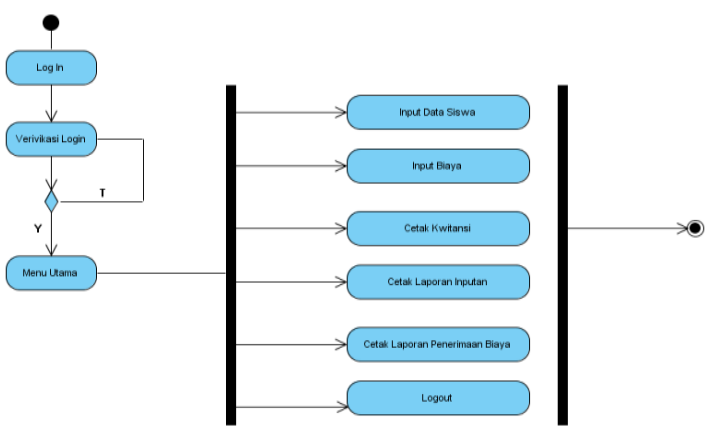

Gambar 5. Activity Diagram untuk petugas TU

Berdasarkan gambar 5. Activity Diagram yang diusulkan di atas, menceritakan bahwa user dan admin harus melakukan login dan apabila login berhasil maka admin dan user dapat masuk pada menu utama dari Program pembayaraan, dan apabila tidak berhasil masuk, maka admin dan user haru mengulang untuk login.

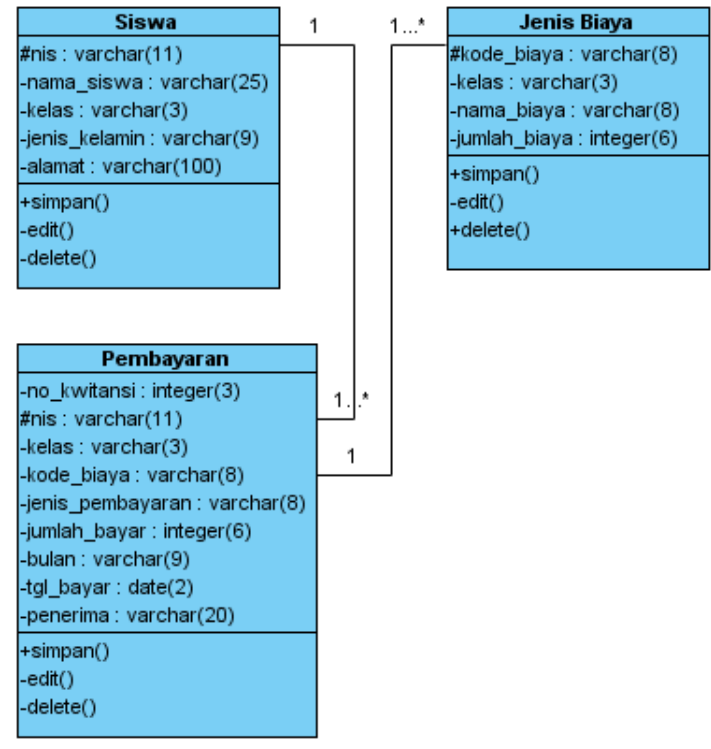

Gambar 5. Class Diagram

Berdasarkan Gambar 5. class diagram yang diusulkan terdapat 3 Class diagram, yang terdiri dari tabel Siswa, Jenis biaya dan pembayaran.dan masing-masing dilengkapi dengan atribut yang dibutuhkan.

Sequence Diagram

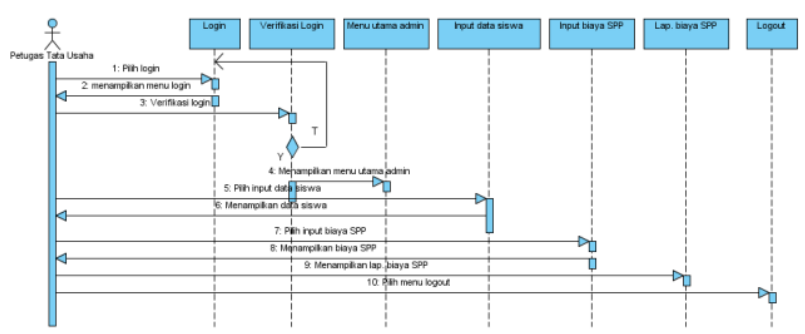

Gambar 7. Sequence Diagram untuk Petugas TU

Berdasarkan gambar 7. sequence diagram yang diusulkan untuk admin sebagai alur dari proses yang sudah disediakan.

State Machine Diagram Yang Diusulkan 


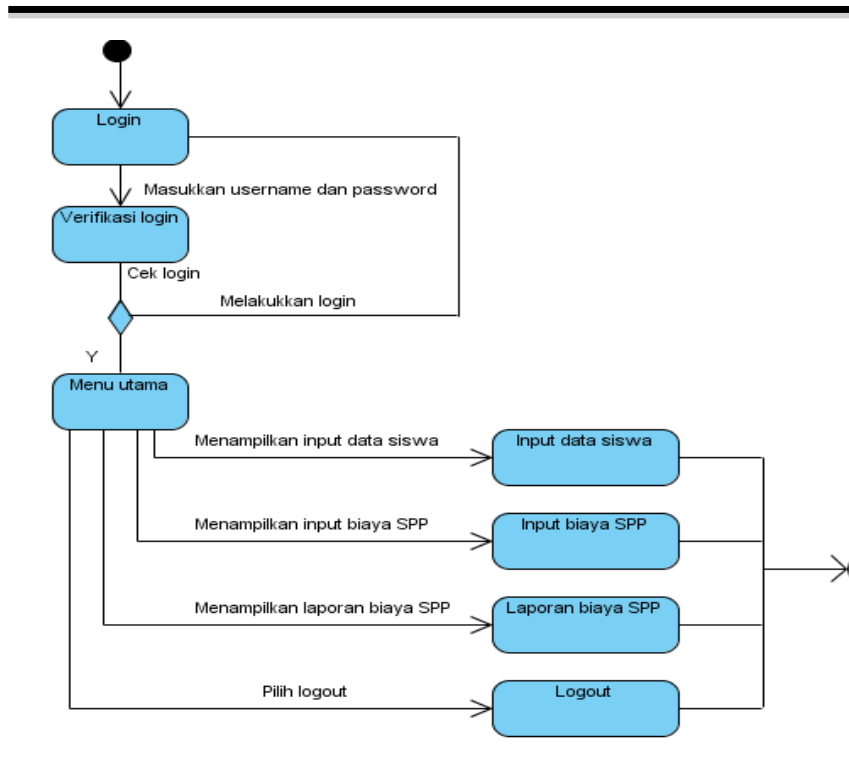

Gambar 8. State Diagram untuk Admin

Berdasarkan Gambar 8. state diagram yang diusulkan user menceritakan bahwa user dan admin harus melakukan login dan apabila login berhasil maka admin dan user dapat masuk pada menu utama dari Program pembayaraan, dan apabila tidak berhasil masuk, maka admin dan user haru mengulang untuk login. Serta memberikan secara rinci kegiatan yang harus dilakukan.

\section{Rancangan Basis Data}

Spesifikasi basis data merupakan desain basis data yang dianggap telah normal. Desain basis data menjelaskan media penyimpanan yang digunakan, isi yang disimpan, primary key, dan panjang record. Spesifikasi basis data yang digunakan dalam sistem yang diusulkan adalah sebagai berikut :

1. Nama File

Media

: Siswa

Isi

$$
\text { : Hard Disk }
$$

nis+nama_siswa+kelas+jenis_kelamin+ala mat

Organisasi File : Index

Primary Key : Nis

Panjang Record : : 148

Type File : File Master

Tabel 1. Tabel Siswa

\begin{tabular}{|c|l|l|c|l|}
\hline No & Field Name & Data Type & Field Size & Keterangan \\
\hline 1. & Nis & Varchar & 11 & Nis Siswa \\
\hline 2. & Nama siswa & Varchar & 25 & Nama siswa \\
\hline 3. & Kelas & Varchar & 3 & Kelas \\
\hline 4. & Jenis,kelamin & Varchar & 9 & Jenis kelamin \\
\hline 5. & Alamat & Varchar & 100 & Alamat \\
\hline
\end{tabular}

2. Nama File : Pembayaran

Media : Hard Disk

Isi : no_kwitansi + nis

+ kelas_kode_biaya + jenis_pembayaran + jumlah_bayar + bulan +

penerima tgl_bayar

Organisasi File : Index

Primary Key : Nis

Panjang Record : :73

Type File : File Master

Tabel .2. Pembayaran

\begin{tabular}{|c|l|l|c|l|}
\hline No & \multicolumn{1}{|c|}{ Field Name } & Data Type & Field Size & Keterangan \\
\hline 1 & No kwitansi & Varchar & 3 & No kwitansi \\
\hline 2 & Nis & Varchar & 11 & Nomor Induk Siswa \\
\hline 3 & Kelas & Varchar & 3 & Kelas \\
\hline 4 & Kode biava & Varchar & 8 & Kode biava \\
\hline 5 & Jenis_pembayaran & Varchar & 8 & Jenis pembavaran \\
\hline 6 & Jumlah_bavar & Currency & 6 & Jumlah bavar \\
\hline 7 & Bulan & Varchar & 9 & Bulan \\
\hline 8 & Tgl_bavar & Date & 5 & Tgl bavar \\
\hline 9 & Penerima & Varchar & 20 & Penerima \\
\hline
\end{tabular}

2. Nama File : Jenis_Biaya

Media : Hard Disk

Isi

kode_biaya+kelas+nama_biaya+jumlah _biaya

Organisasi File : Index

Primary Key : : kode_biaya

Panjang Record : :37

Type File : File Master 
Tabel 3. Tabel Jenis Biaya

\begin{tabular}{|c|l|c|c|l|}
\hline No & Field Name & Data Type & Field Size & Keterangan \\
\hline 1 & Kode biava & Varchar & 8 & Kode biaya \\
\hline 2 & Kelas & Varchar & 3 & Kelas \\
\hline 3 & Nama biava & Varchar & 50 & Nama biava \\
\hline 4 & Jumlah biava & Integer & 6 & Jumlah biava \\
\hline
\end{tabular}

\section{Tampilan Layar}

Pada tampilan layar menu utama atau index berada pada halaman login, pada halaman berfungsi sebagai hak akses terhadap user maupun admin yang masingmasing memiliki tugasnya tersendiri, dan pada aplikasi pembayaran uang sekolah terdapat menu atau fasilitas pembayaran Uang Sekolah yang didalamnya mempunyai submenu pembayaran spp, data pembayaran siswa, referensi data yang mempunyai submenu pembayaran, siswa dan user, laporan mempunyai sub menu data pembayaran Uang Sekolah siswa, rekap mempunyai submenu laporan pembayaran siswa dan menu keluar.

\section{Tampilan Login}

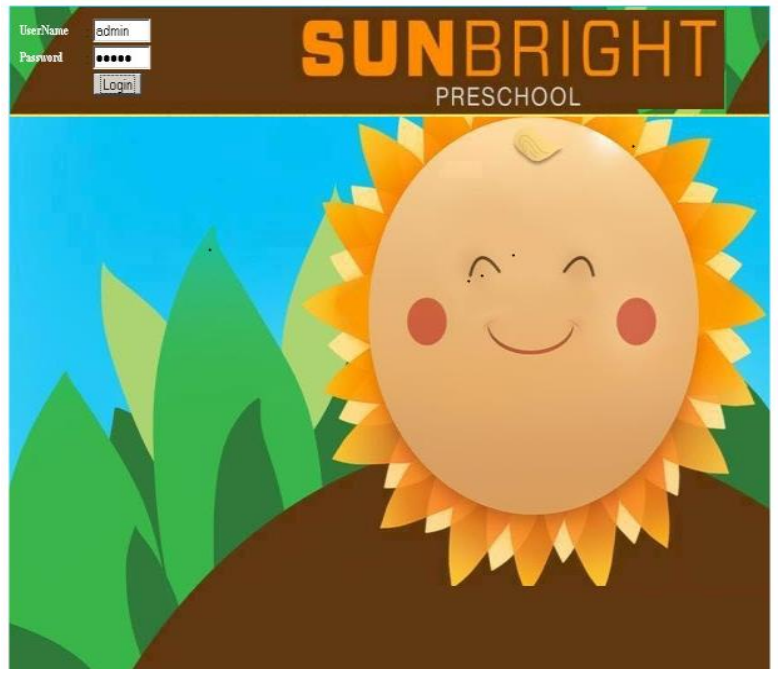

Gambar 9. Tampilan Login

\section{Tampilan Menu Utama}

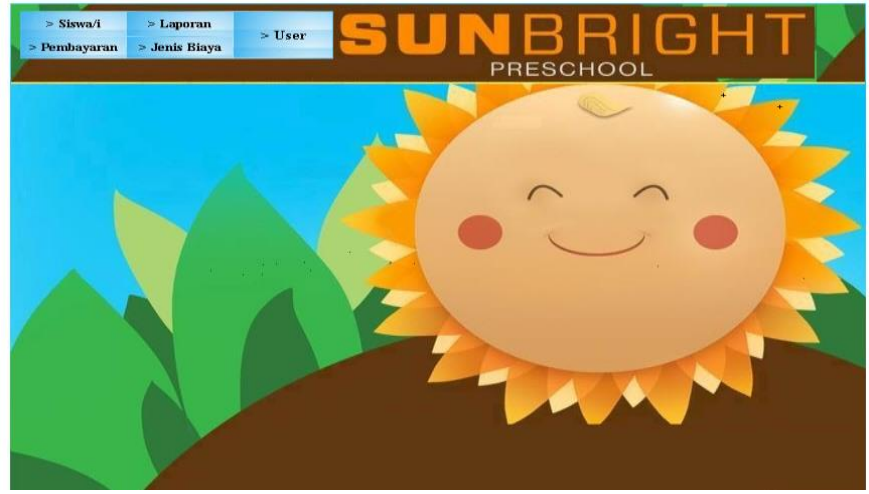

Gambar 10. Tampilan Menu Utama

\section{Tampilan Menu Siswa}

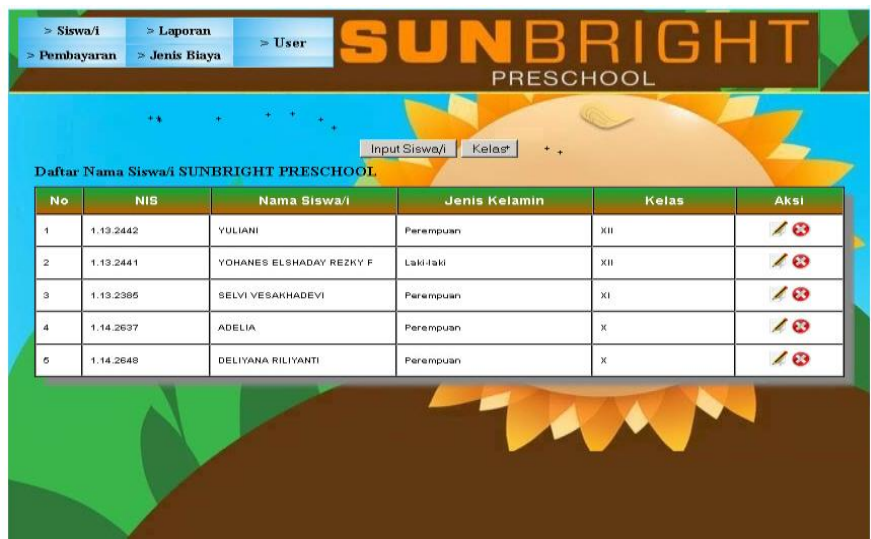

Gambar 11. Tampilan Menu Siswa

\section{Tampilan Menu Pencarian Siswa}

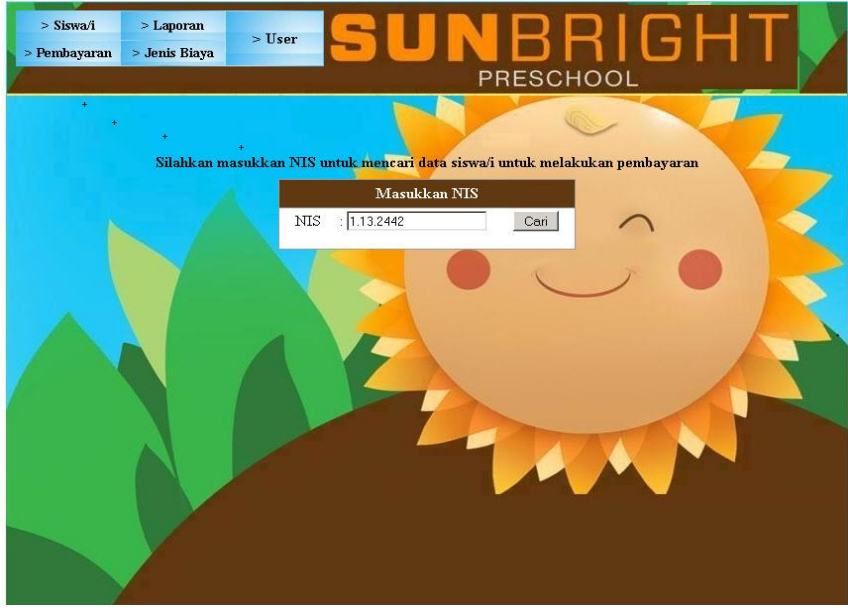

Gambar 12. Tampilan Menu Pencarian Siswa 


\section{Tampilan Menu Pembayaran Siswa}

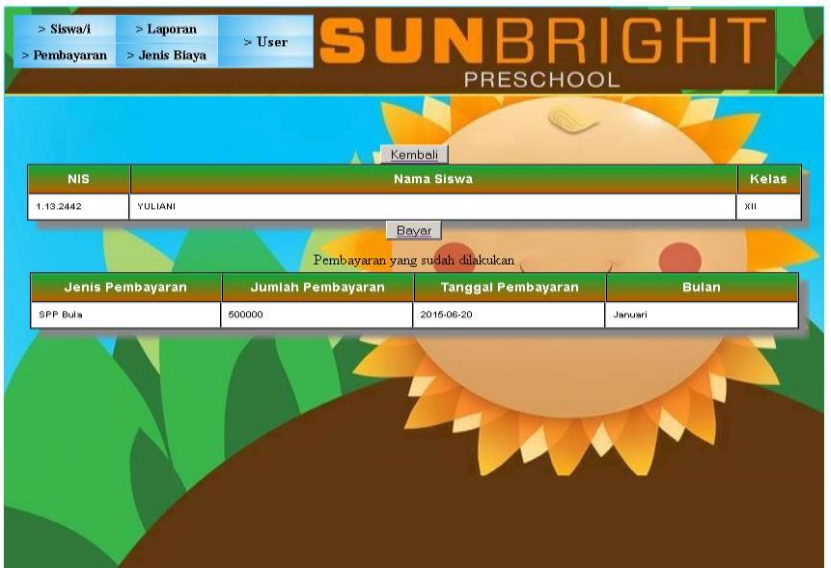

Gambar 13. Tampilan Menu Pembayara

\section{Tampilan Menu Jenis Pembayaran}

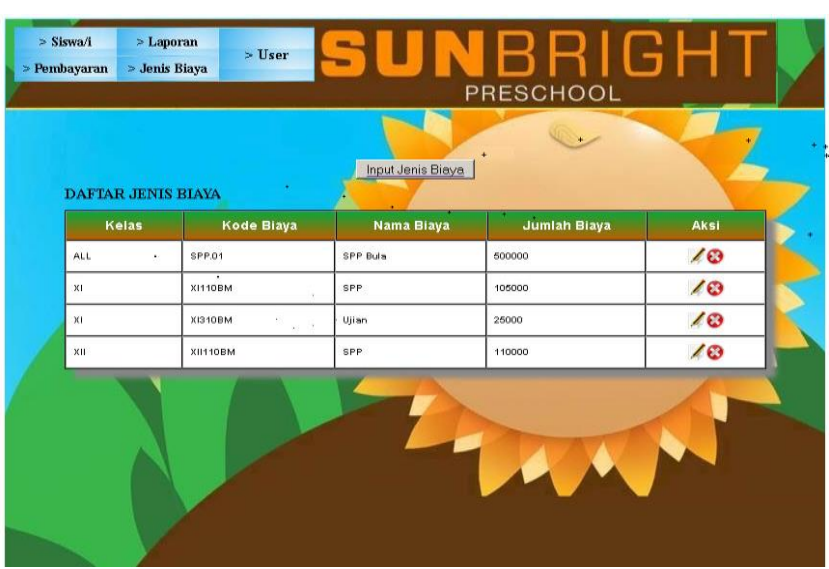

Gambar 14. Tampilan Menu Jenis Pembayaran

\section{Tampilan Menu Laporan Cetak}

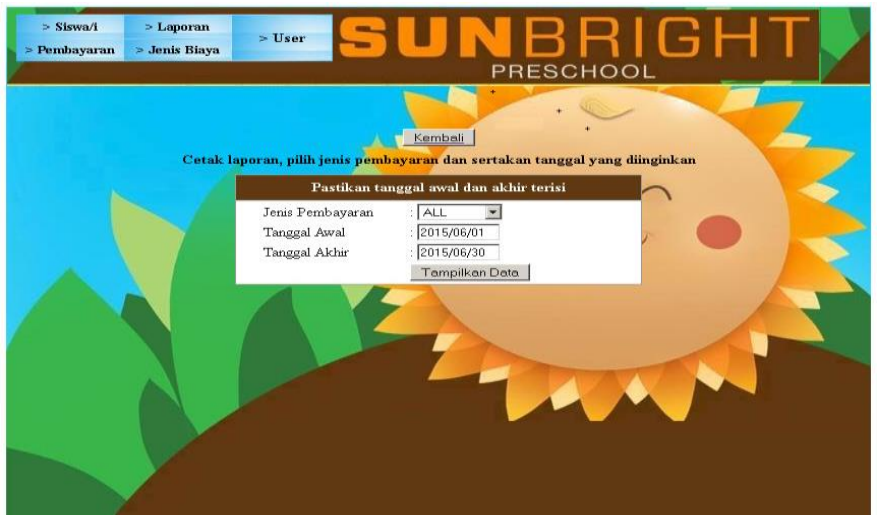

Gambar 15. Tampilan Menu Laporan

Cetak Pembayaran

\section{Tampilan Hasil cetak Kuitansi}

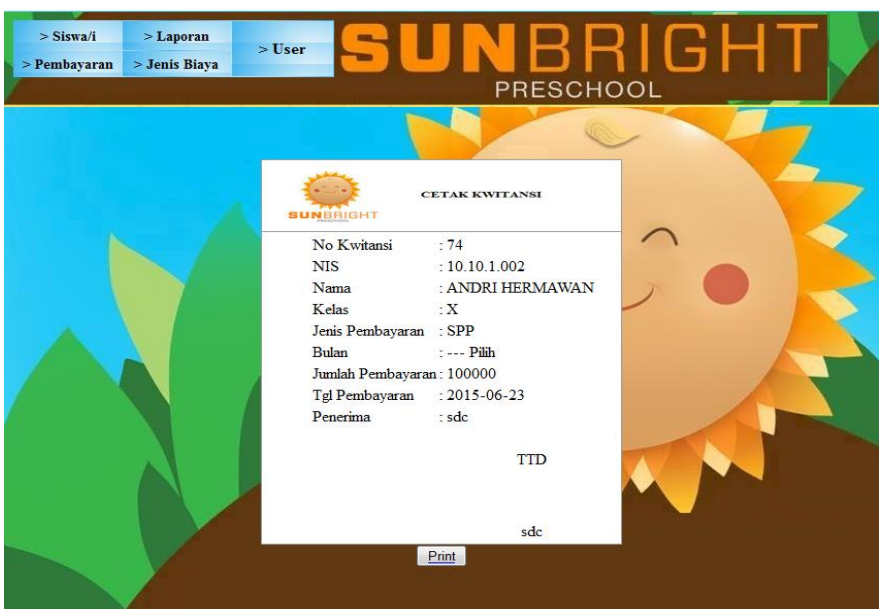

Gambar 16. Tampilan Hasil Cetak Kwitansi

\section{Tampilan Menu Laporan Pembayaran}




\section{LAPOIRAN IKEUANGGAN}

Laporan Pembayaran
\begin{tabular}{|c|c|c|c|c|c|c|c|}
\hline No & $\begin{array}{c}\text { Tanggal } \\
\text { Pembayaran }\end{array}$ & NIS & Nama & Kelas & $\begin{array}{c}\text { Jenis } \\
\text { Pembayaran }\end{array}$ & Bulan & Uang (Rp) \\
\hline 1 & $2015-06-20$ & 1.13 .2442 & YULIANI & XII & SPP Bula & Januari & $500.000,00$ \\
\hline
\end{tabular}

Gambar 17. Tampilan Menu Laporan Pembayaran

\section{Implementasi Diusulkan \\ Aplikasi \\ Yang}

Adapun bahasa pemrograman dan database yang digunakan adalah PHP, MySql, Macromedia CS3, dan XAMPP.

Rancangan Perangkat Keras (Hardware) Perangkat keras yang dibutuhkan oleh aplikasi atau sistem adalah suatu unit personal komputer. Perangkat keras yang diusulkan ini dibuat berdasarkan kebutuhan sistem saat ini dan antisipasi kebutuhan di masa yang akan datang. Konfigurasi yang dibutuhkan pada desain sistem yang diusulkan adalah :

1. Perangkat Keras (hardware) yang digunakan admin dosen sebagai berikut :
a. Processor : Intel Pentium 4
b. Monitor : 14" LCD monitor
c. Mouse :Optical PS
d. Keyboard :PS 2
e. $R A M \quad: 1 G B$
f. Harddisk : $80 \mathrm{~GB}$

Instalasi Perangkat Lunak (Software) Dalam pembuatan program ini peneliti menggunakan software:

1. Sistem Operasi Windows XP.

2. Adobe Dreamweaver CS 3.

3. Mozila firefox
4. XAMMP untuk pembuatan database

5. Visual Paradigm 6.4 Enterprise Edition

6. Microsoft Office 2007.

Hak Akses (Brainware)

Hanya admin (User) \& Administrator yang dapat meng-akses Aplikasi Pembayaran Uang Sekolah

Testing

Metode pengujian yang digunakan yaitu Black Box Testing. Black box testing adalah pengujian yang dilakukan hanya mengamati hasil eksekusi melalui data uji dan memeriksa fungsional dari perangkat lunak. Metode pengujian Black Box berusaha untuk menemukan kesalahan dalam beberapa katagori, diantaranya: fungsi-fungsi yang salah atau hilang.

\section{KESIMPULAN}

Berdasarkan permasalahan dan penjelasan yang ada dapat ditarik beberapa kesimpulan diantaranya adalah sebagai berikut:

1. Sistem informasi pembayaran Uang Sekolah ini masih menggunakan sistem yang semikomputerisasi sehingga pengolahannya menjadi rumit mulai dari proses pembayaran, 
proses penginputan data pembayaran sampai pada proses pembuatan laporan yang kurang efektif.

2. Kendala dalam proses pembayaran Uang Sekolah ini ialah pada waktu penginputan data yang masih menggunakan Microsoft excel sampai dengan proses penghitungan yang berulang-ulang menyebabkan hasil laporan pembayaran Uang Sekolah tersebut menjadi tidak akurat dan maksimal.

3. Untuk merancang sebuah Sistem informasi pembayaran Uang Sekolah yang efektif dan efisien maka dibutuhkan Sistem Informasi pembayaran Uang Sekolah berbasis web dengan bahasa pemrograman php dan mysql sebagai penyimpanan databasenya.

\section{DAFTAR PUSTAKA}

[1] Amrullah Afif, (2011). LangkahLangkah Penggunaan UML (Unified Modeling Language), Bandung.

[2] Anhar, (2010). Pengertian PHP,. MediaKom, Yogyakarta.

[3] Jan Ondrus, pigner Yves, (2010), Cross-industri Preferensi Pengembangan Mobile Pembayaran di Swiss. Swiss.

[4] Jogiyanto, (2009). Tujuan Sistem Informasi, Komponen Sistem Informasi, Klasifikasi Sistem dan Karakteristik Sistem, Mediakita, Jakarta

[5] Juwaeni Ahmad, (2011), Analisa Sistem Administrasi Pembayaran Sekolah Pada SMA Negeri 1 Pasar Kemis. Tangerang.

[6] Kristanto, (2010). Tahap dan Kegiatan Perancangan Sistem. CV Andi Offset. Yogyakarta
[7] Kusrini, (2007). Desain / Perancangan Sistem. InsanMulia, Jakarta.

[8] Malasari Nur Desy, (2009), "Analisa dan Perancangan Sistem Informasi Pembayaran SPP Sekolah Pada SMK YP Karya Bangsa. Tangerang.

[9] Petter John, (2009), Kriteria Database. Jawa Tengah

[10] Purwanti Desi, (2011) Perancangan Sistem Administrasi Pembayaran Sekolah Berbasis Web Pada SMA Negeri 6 Tangerang, Tangerang.

[11]Rosyid, Al, Harun, (2011), Definisi Perancangan Sistem. semarang.

[12]Sanita, (2010), Perancangan Sistem Pembayaran SPP Sekolah Berbasis Web Pada SMP PGR1 396 Kelapa Dua, Tangerang.

[13]Sugiarto Mozes, (2009), Definisi XAMPP, Jakarta.

[14]Sutarman, (2012), Definisi Sistem,. CV Andi Offset. Yogyakarta. 